\title{
Inkuiri Terbimbing untuk Meningkatkan Keterampilan Proses Sains Siswa Sekolah Menengah Atas
}

\author{
Suyono \\ SMA Negeri 2 Madiun \\ Email: suyonosynway@gmail.com \\ dikirim : 20 Juli 2019, direvisi: 5 Agustus 2019, diterima : 5 Agustus 2019
}

\begin{abstract}
Abstrak
Penelitian ini bertujuan untuk mengetahui peningkatan keterampilan proses sains siswa dengan pendekatan inkuiri terbimbing pada siswa kelas XI IPA7 SMA Negeri 2 Madiun Tahun Pelajaran 2015/2016. Jenis penelitian ini adalah penelitian tindakan kelas (action research) dengan tahapan perencanaan, tindakan, observasi dan refleksi. Data dikumpulkan dengan tes tertulis untuk keterampilan. Pembelajaran dengan pendekatan inkuiri terbimbing memiliki dampak positif dalam meningkatkan keterampilan proses sains siswa yang ditandai dengan ketuntasan secara klasikal dari siklus I $(46,26 \%)$ menjadi $(83,22)$ pada siklus II. Hasil belajar keterampilan siswa meningkat setelah mengikuti pembelajaran model IDL Terbimbing dengan persentase ketuntasan klasikal dari siklus I $(62,50 \%)$ menjadi $(90,63 \%)$ pada siklus II.
\end{abstract}

Kata Kunci : inkuiri terbimbing, keterampilan proses sains, tindakan kelas

\section{Inquiry Considered to Improve Skills of Science Process Students in Senior High School}

\author{
Suyono \\ SMA Negeri 2 Madiun \\ Email: suyonosynway@gmail.com
}

\begin{abstract}
This study aims to determine the improvement of science process skills of students with guided inquiry approach in class XI IPA7 of SMA Negeri 2 Madiun 2015/2016 Academic Year. Classroom action research methods (action research) data collected with written tests for skills. Learning with guided inquiry approaches has a positive impact in improving student science process skills which are characterized by classical completeness from cycle I (46.26\%) to (83.22) in cycle II. Learning outcomes of students' skills increased after following the Guided IDL model learning with the percentage of classical completeness from cycle I (62.50\%) to (90.63\%) in cycle II.
\end{abstract}

Keywords: guided inquiry, science process skills, action research 


\section{PENDAHULUAN}

Pengetahuan tentang Sains seharusnya mulai diperhatikan dan dikaji oleh semua civitas pendidikan sehingga siswa dan guru memahami Sains khususnya Fisika dengan baik (Jumanto \& Widodo, 2018). Dalam mencapai tujuan pembelajaran pada mata pelajaran fisika di Sekolah Menengah Atas, khususnya di kelas XI IPA7 SMA N 2 Madiun masih banyak mengalami kesulitan. Hal ini terlihat dari masih rendahnya nilai mata pelajaran Fisika dibandingkan dengan nilai beberapa mata pelajaran lainnya, mata pelajaran Fisika peringkat nilainya menempati urutan paling bawah dari mata pelajaran yang lainnya, bertitik tolak dari hal tersebut di atas perlu pemikiran-pemikiran dan tindakantindakan yang harus dilalukan agar siswa dalam mempelajari konsep-konsep fisika tidak mengalami kesulitan, sehingga tujuan pembelajaran yang dibuat oleh guru mata pelajaran Fisika dapat tercapai dengan baik dan hasilnya dapat memuaskan semua pihak. Ditinjau dari karakteristik materi ajar fisika, pembelajaran fisika lebih diarahkan untuk inkuiri dan berbuat sehingga dapat membantu peserta didik untuk memperoleh pemahaman yang lebih mendalam tentang alam sekitar. Melalui inkuiri siswa berusaha sendiri untuk mencari pemecahan masalah serta pengetahuan yang menyertainya, menghasilkan pengetahuan yang benar-benar bermakna. Bruner menyarankan agar siswasiswa belajar dengan partisipasi secara aktif. Para siswa dianjurkan untuk memperoleh pengalaman dan melakukan eksperimeneksperimen yang mengizinkan mereka untuk menemukan prinsip-prinsip itu sendiri.

Berdasarkan hasil observasi langsung yang peneliti lakukan pada bulan Desember tahun 2016 di kelas XI IPA7 SMA Negeri 2 Madiun, diperoleh: (1) proses pembelajaran fisika yang digunakan sudah menunjukkan adanya interaksi dua arah antara guru dan siswa, (2) dalam pembelajaran fisika jarang melakukan percobaan/praktikum, (3) dari angket yang disebar $40 \%$ dari 32 siswa menganggap materi fisika sulit, (4) minat siswa terhadap percobaan dalam fisika agar lebih menyenangkan cukup besar yaitu $77,97 \%$ dari 32 siswa, (5) dari beberapa pertanyaan pendahuluan keterampilan proses sains meliputi kemampuan identifikasi variabel, definisi operasional, dan kesimpulan persentasi jawaban benar siswa masingmasing hanya $19,2 \%, 0 \%$ dan $27,2 \%$, (6) ketuntasan hasil belajar siswa pada ulangan bulanan tentang elastisitas bahan pada semester ganjil tahun ajaran 2015/2016 dimana siswa yang tidak tuntas sebesar $78,8 \%$ dari 32 siswa, dengan Kriteria Ketuntasan Minimal (KKM) yang ditetapkan sekolah yaitu sebesar 75 .

\section{Inquiry Discovery Learning (IDL)} Terbimbing merupakan salah satu upaya untuk mengatasi permasalahan diatas perlu diterapkan. IDL Terbimbing adalah suatu model pembelajaran dimana siswa belajar dalam kelompok-kelompok penyelidikan untuk melatih keterampilan proses sains dan 
pemecahan masalah akademik dengan bantuan penuntun atau Lembar Kerja Siswa (LKS). Fase-fase pembelajaran IDL: mengorientasikan masalah, merancang eksperimen, melaksanakan eksperimen melakukan infrensi/prediksi dan merefleksi pemecahan masalah. Keterampilan proses sains adalah keterampilan yang dipelajari siswa pada saat mereka melakukan inkuiri ilmiah (Nur, 2008 ), yang ditekankan pada merumuskan hipotesis, mengidentifikasi variabel, mendefinisikan variabel secara operasional, menganalisis data, memprediksi serta menarik kesimpulan.

Fluida statis merupakan materi ajar yang sesuai dengan model IDL, karena Kompetensi Dasar dari materi ini adalah menganalisis hukum-hukum yang berhubungan dengan fluida statik dan dinamik serta penerapannya dalam kehidupan sehari-hari. Untuk menganalisis hukum-hukum yang berhubungan dengan fluida statik dan dinamik serta penerapannya dalam kehidupan seharihari tentu akan lebih menarik dengan penyelidikan melalui percobaan langsung. Adanya keterlaksanaan Rencana Pelaksanaan Pembelajaran (RPP) dengan penerapan model IDL Terbimbing model dan Adanya peningkatan hasil belajar keterampilan siswa setelah diterapkan pembelajaran dengan menggunakan IDL Terbimbing.

\section{METODE PENELITIAN}

Penelitian ini merupakan penelitian tindakan (action research), karena penelitian dilakukan untuk memecahkan masalah pembelajaran di kelas. Penelitian tindakan kelas ini mencakup 2 siklus dn masing-masing siklus terdiri dari perencanaan, tindakan, observasi dan refleksi. Penelitian ini juga termasuk penelitian deskriptif, sebab menggambarkan bagaimana suatu teknik pembelajaran diterapkan dan bagaimana hasil yang diinginkan dapat dicapai. Menurut Oja dan Sumarjan (dalam Titik Sugiarti, 1997: 8) mengelompokkan penelitian tindakan menjadi empat macam yaitu: (a) guru sebagai penelitia (b) penelitian tindakan kolaboratif (c) simultan terintegratif (d) administrasi social eksperimental.

Dalam penelitian tindakan ini menggunakan bentuk guru sebagai peneliti, penanggung jawab penuh penelitian ini adalah guru. Tujuan utama dari penelitian tindakan ini adalah untuk meningkatkan hasil pembelajaran di kelas dimana guru secara penuh terlibat dalam penelitian mulai dari perencanaan, tindakan, pengamatan, dan refleksi. Hasil belajar meliputi aspek kognitif, afektif , dan aspek psikomotorik (Syafi'i, Marfiyanto, \& Rodiyah, 2018). Dalam penelitian ini peneliti tidak bekerjasama dengan siapapun, kehadiran peneliti sebagai guru di kelas sebagai pengajar tetap dan dilakukan seperti biasa, sehingga siswa tidak tahu kalau diteliti. Dengan cara ini diharapkan didapatkan data yang seobjektif mungkin demi kevalitan data yang diperlukan. 


\section{HASIL DAN PEMBAHASAN}

\section{Siklus I}

Keterampilan proses sains, dengan penerapan model IDL terbimbing pada siklus I ternyata hanya 6 dari 32 siswa yang keterampilan proses sains tuntas secara individual. Bahwa pada siklus I keterampilan proses sains siswa $(25,28 \%)$ secara klasikal belum tercapai, karena lebih kecil dari persentase ketuntasan yang dikehendaki
(85\%). Hal ini dikarenakan siswa masih merasa baru dan belum terbiasa menggunakan keterampilan proses sains daam pembelajaran seperti mengidentifikasi variabel dan mendefinisi operasional variabel, menganalisis, membuat prediksi serta kesimpulan. Penguasaan keterampilan proses sains siswa pada siklus I dapat dilihat pada Tabel 1

Tabel 1. Penguasaan Keterampilan Proses Sains Siklus I

\begin{tabular}{lc}
\hline Keterampilan Proses Sains yang Dinilai/Diamati & Persentase (\%) \\
\hline Merumuskan Hipotesis & 81,8 \\
Mengidentifikasi Variabel & 61,2 \\
Membuat Definisi Operasional Variabel & 44,2 \\
Menganalisis & 51,2 \\
Membuat Prediksi/Infrensi & 9,06 \\
Membuat Kesimpulan & 30,1 \\
Rata-rata & $46,26 \%$ \\
\hline
\end{tabular}

Dapat di artikan bahwa dengan table 1 terampil sehingga dalam pelaksanaan siswa belum benar-benar paham dengan percobaan terutama saat pengambilan data proses keterampilan proses sains serta masih memakan waktu yang cukup lama. Sedangkan terlihat canggung dengan percobaan itu hasil belajar keterampilan seperti pada Tabel sendiri, tampak juga dari penggunaan dan 2 . pembacaan alat ukur yang masih belum

Tabel 2. Analisis Hasil Belajar Keterampilan pada Siklus I

\begin{tabular}{|c|c|c|}
\hline No & Uraian & Siklus I \\
\hline 1 & Jumlah siswa yang tuntas belajar & 20 \\
\hline 2 & Jumlahsiswa seluruhnya & 32 \\
\hline 3 & Persentase ketuntasan belajar (ketuntasan klasikal) & $62,5 \%$ \\
\hline
\end{tabular}

Sesuai data pada tabel 2, pembelajaran dengan model IDL Terbimbing pada siklus I ternyata hanya 20 dari 32 siswa yang hasil belajar produknya tuntas secara individual. Hasil tersebut menunjukkan bahwa pada siklus I secara klasikal $(62,5 \%)$ belum tercapai lebih kecil dari persentase ketuntasan yang dikehendaki (85\%). Hal ini disebabkan karena siswa masih merasa baru dengan pembelajaran model IDL sehingga mereka kurang bisa berkonsentrasi untuk memahami bentuk soal hitungan serta jumlah soal yang cukup banyak (karena mereka mengerjakan soal produk dan proses) sedangkan waktu untuk mengerjakan tes sedikit. Keterlaksanaan RPP pada siklus I secara garis besar kegiatan 
belajar mengajar menggunakan model IDL Terbimbing sudah dilaksanakan $96 \%$.

\section{Siklus II}

Untuk keterampilan proses sains dengan menerapkan model IDL Terbimbing pada siklus II sudah ada 29 dari 32 siswa yang keterampilan proses sains tuntas secara individual. Hasil tersebut menunjukkan bahwa pada siklus II keterampilan proses sains siswa $(90,63 \%)$ secara klasikal belum tercapai, karena lebih kecil dari persentase ketuntasan yang dikehendaki (85\%). Hasil pada siklus II ini jauh lebih baik dibandingkan pada siklus I artinya ada peningkatan keterampilan proses sains oleh siswa pada siklus ini. Hal ini dikarenakan siswa sudah bisa beradaptasi dan lebih memahami model pembelajaran ini, disamping itu karena adanya perbaikan dari hasil refleksi pada siklus I. Penguasaan keterampilan proses sains siklus II dapat dilihat pada Tabel 3.

Persentase penguasaan keterampilan proses sains meningkat dari $46,26 \%$ menjadi $83,22 \%$ jika dibandingkan dengan siklus I sedangkan untuk hasil belajar keterampilan dapat dilihat tabel 4.

Tabel 3. Penguasaan Keterampilan Proses Sains Siklus II

\begin{tabular}{lc}
\hline Keterampilan Proses Sains yang Dinilai/Diamati & Persentase (\%) \\
\hline Merumuskan Hipotesis & 80,8 \\
Mengidentifikasi Variabel & 90,9 \\
Membuat Definisi Operasional Variabel & 77,6 \\
Menganalisis & 82,7 \\
Membuat Prediksi/Infrensi & 81,8 \\
Membuat Kesimpulan & 85,5 \\
Rata-rata & $83,22 \%$ \\
\hline
\end{tabular}

Tabel 4. Analisis Hasil Belajar keterampilan pada Siklus II

\begin{tabular}{clc}
\hline No & \multicolumn{1}{c}{ Uraian } & Siklus II \\
\hline 1 & Jumlah siswa yang tuntas belajar & 30 \\
2 & Jumlah siswa seluruhnya & 32 \\
3 & Persentase ketuntasan belajar (ketuntasan klasikal) & $93,75 \%$ \\
\hline
\end{tabular}

Dengan menerapkan model IDL Terbimbing pada siklus II ada 30 dari 32 siswa yang tuntas secara individual. Hasil tersebut menunjukkan bahwa pada siklus II secara klasikal $(93,75 \%)$ lebih besar dari persentase ketuntasan yang dikehendaki $(85 \%)$. Sementara untuk hasil analisis keterlaksanaan RPP pada siklus II secara garis besar kegiatan belajar mengajar menggunakan model IDL Terbimbing sudah dilaksanakan $100 \%$.

\section{KESIMPULAN DAN SARAN}

Dari hasil kegiatan pembelajaran yang telah dilakukan selama penelitian, dan berdasarkan seluruh pembahasan serta analisis yang telah dilakukan dapat disimpulkan sebagai berikut:

(1) Keterampilan proses sains siswa yang mengikuti pembelajaran dengan menggunakan model IDL Terbimbing meningkat dari siklus I $(46,26 \%)$ menjadi $(83,22)$ pada siklus II. (2) Hasil belajar keterampilan siswa meningkat setelah mengikuti pembelajaran model IDL Terbimbing 
dengan persentase ketuntasan klasikal dari siklus I $(62,50 \%)$ menjadi $(90,63 \%)$ pada siklus II. (3) Persentase keterlaksanaan RPP yang meningkat dari $(96 \%)$ pada siklus I menjadi (100\%) pada siklus II. Sehingga kesimpulan secara umum bahwa penerapan model Inquiry Discovery Learning (IDL) terbimbing pada materi ajar mekanika fluida di kelas XI IPA 7 SMA Negeri 2 Madiun efektif dalam meningkatkan keterampilan proses sains siswa

Agar proses belajar mengajar Fisika lebih efektif dan lebih memberikan hasil yang optimal bagi siswa, menyimak hasil penelitian yang diperoleh dari uraian sebelumnya maka disarankan. Model IDL memerlukan persiapan yang cukup matang, terutama dalam hal pengaturan waktu sehingga guru harus mampu menentukan atau memilih topik yang benar-benar bisa diterapkan dengan metode pembelajaran model IDL Terbimbing dalam proses belajar mengajar sehingga diperoleh hasil yang optimal.

\section{DAFTAR PUSTAKA}

Arend, R.I. (2008). Learning To Teach. Yogyakarta: Pustaka Pelajar

Arikunto, S. (2008). Manajemen Penelitian. Jakarta: PT.Rineka Cipta. (2009). Prosedur Penelitian, Suatu Pendekatan Praktek. Jakarta: PT.Rineka Cipta.

Borich, G. D \& Choo Ong, Ai. (2006). Teaching Strategies That Promote Thinking, Model and Curriculum Approaches. McGraw-Hill: Education Asia.

Haryono, E. (2001). Peningkatan Kualitas pembelajaran Fisika SLTP Berdasarkan Model Penemuan Terbimbing (Guided Discovery). Tesis. Tidak Dipublikasikan. Surabaya: Unesa.

Hamalik, O. (1993). Strategi belajar mengajar. Bandung: Mandar Maju.

Handayani, S. (2009). Fisika Untuk SMA dan MA Kelas XI. Jakarta: Departemen Pendidikan Nasional

Jamal, A. M. (2009). Pengembangan Teknik Pemodelan Fisika Melalui Pengajaran
Langsung pada Perkuliahan Fisika Dasar. Tesis. Tidak Dipublkasikan. Surabaya: Unesa.

Joice, W. (1992). Models of Teaching fifth edition. A Simon \& Schuster Company, Printed in the United States of America.

Jumanto, J., \& Widodo, A. (2018). PEMAHAMAN HAKIKAT SAINS OLEH SISWA DAN GURU SD DI KOTA SURAKARTA. Jurnal Komunikasi Pendidikan, 2(1), 20-31.

Kanginan, M. (2007). Fisika untuk SMA kelas X Semester 2. Jakarta: Erlangga

Nur, M. (2008). Pembelajaran Kooperatif edisi 2. Surabaya: Unesa.

Nur, M. (2008). Pengajaran Berpusat kepada Siswa dan Pendekatan Kontruktivis dalam Pengajaran edisi 3. Surabaya: Unesa

Syafi'i, A., Marfiyanto, T., \& Rodiyah, S. K. (2018). STUDI TENTANG PRESTASI BELAJAR SISWA DALAM BERBAGAI ASPEK DAN FAKTOR YANG MEMPENGARUHI. Jurnal Komunikasi Pendidikan, 2(2), 115-123. 